\title{
Meningkatkan Hasil Belajar Matematika Melalui Pembelajaran Team Assisted Individualization pada Siswa Kelas VII-1 SMP Negeri 32 Pekanbaru
}

\author{
Poritas \\ Sekolah Menengah Pertama Negeri 32 Pekanbaru \\ e-mail: poritasitas@yahoo.com
}

\begin{abstract}
ABSTRAK. Sebagai seorang guru matematika yang mengajar kelas VII di SMP Negeri 32 Pekanbaru. Peneliti merasa bertanggung jawab terhadap kegagalan siswa dalam pembelajaran. Pada kelas VII-1 tempat peneliti mengajar, terdapat masalah yang perlu diselesaikan, diantaranya yaitu aktivitas dan hasil belajar matematika siswa sangat rendah. Sebagian siswa pasif dan tidak mau bertanya apabila menemui kesulitan belajar matematika. Nilai siswa yang mencapai KKM $\geq 80$ sebesar 43,8 \%. Berdasarkan permasalahan tersebut, perlu aktivitas dan hasil belajar matematika siswa perlu ditingkatkan melalui model pembelajaran kooperatif tipe Team Assisted Individualization Siswa Kelas VII-1 SMP Negeri 32 Pekanbaru Tahun 2018. Metode yang digunakan yaitu dengan Penelitian Tindakan Kelas. Kegiatan yang dilakukan meliputi perencanaan, pelaksanaan, observasi, dan refleksi. Data kegiatan tersebut dikumpulkan melalui hasil pengamatan pada setiap akhir siklus. Analisis data menggunakan kualitatif dan kuantitatif. Adapun hasil penelitian Tindakan Kelas yaitu Dari hasil belajar pada siklus I siswa yang tuntas belajar dari pertemuan 1, 2 dan 3 rata-rata adalah 66,7\% pada siklus ke 2 meningkat menjadi 87,1\% naik sebesar 20,4\% Ketidak tuntasan belajar siswa disebabkan kemampuan kongkrit mereka yang kurang, oleh karena itu perlu bimbingan dan perhatian dari guru, dari hasil tersebut menunjukkan bahwa indikator hasil belajar $75 \%$ siswa yang memperoleh nilai 80 sudah tercapai pada siklus 2
\end{abstract}

Keywords : Model Pembelajaran Team Assisted Individual, Hasil Belajar Matematika, Penelitian Tindakan Kelas.

ABSTRACT. As a mathematics teacher who taught class VII at SMP N 32 Pekanbaru. Researchers feel responsible for students' failures in learning. In class VII-1 where researchers teach, there are problems that need to be resolved, including the activities and student learning outcomes of mathematics that are very low. Some students are passive and do not want to ask if they have difficulty in learning mathematics. The students scores who reach $\mathrm{KKM} \geq 80$ is $43.8 \%$. Based on these problems, it is necessary to improve the activities and mathematics learning outcomes of students through the cooperative learning model type Team Assisted Individualization Class VII-1 SMP N 32 Pekanbaru in 2018. The research method used is Classroom Action Research. Activities carried out include planning, implementation, observation, and reflection. The activity data is collected through observations at the end of each cycle. Data analysis using qualitative and quantitative. The results of Classroom Action research, namely from the learning outcomes in the first cycle students who complete learning from meetings 1, 2 and 3 on average are $66.7 \%$ in the second cycle increased to $87.1 \%$ up by $20.4 \%$ Learning incompleteness students are due to their lack of concrete abilities, therefore need guidance and attention from the teacher, from these results indicate that indicators of learning outcomes $75 \%$ of students who get a value of 80 have been reached in cycle 2 .

Keywords : Team Assisted Individualized Model, Learning Results in Mathematics, Class Action Research. 


\section{PENDAHULUAN}

Hasil belajar merupakan tujuan akhir dari proses pendidikan (Kurniawan, Wiharna, \& Permana, 2017). Menurut Gagne (1983) salah satu kategori hasil belajar yaitu kemampuan intelektual, dapat dilihat ketika siswa mampu menerapkan barisan konsep yang menggambarkan kondisi dan aksi ke dalam situasi umum. Selain itu, hasil belajar juga dapat menggambarkan keefektifan hasil pembelajaran (Sutrisno, 2016). Keberhasilan suatu hasil pembelajaran, salah satunya ditentukan oleh guru. Guru harus dapat menggunakan model pembelajaran yang tepat pada kondisi siswa tertentu untuk materi yang tertentu. Oleh karena itu, guru dituntut harus mampu merancang dan melaksanakan progra pengalaman belajar dengan tepat, agar siswa memperoleh pengetahuan secara holistik sehingga pelajaran menjadi bermakna bagi siswa.

Rendahnya hasil belajar siswa menjadi persoalan serius yang harus segera dicarikan solusinya. Kajian global terkait hasil belajar matematika maih sangat rendah. Hal ini dapat dilihat melalui rangking PISA pada tahun 2015 yaitu 62 dari 72 negara (Nuraheni, 2016). selain itu, kajian TIMSS yang dirilis pada tahun 2015 juga menunjukkan rendahnya skor matematika siswa Indonesia yaitu 397 poin dengan peringkat 45 dari 50 negara peserta (Bernas.id, 2017).

Penelitian tentang hasil belajar yang melibatkan guru sebagai peneliti menjadi penting. Utamanya usaha dalam meningkatkan hasil belajar. Beberapa penelitian tindakan terkait dengan hasil belajar telah banyak dilakukan (Aminah, 2017; Maysarah, 2018; Subroto \& Slameto, 2015; Sutrisno, 2016; Syafwan, 2013; Yusuf, 2010). Akan tetapi, penelitian ini hanya berlaku untuk kondisi tertentu. Oleh karena itu, diperlukan landasan yang lebih kokoh agar penelitian yang dilakukan benar-benar dapat meningkatkan hasil belajar siswa.

Rendahnya hasil belajar juga ditemui di SMP Negeri 32 Pekanbaru, tempat Peneliti mengajajar. Pada kelas VII-1 tempat peneliti mengajar, aktivitas dan hasil belajar siswa di dalam pembelajaran matematika sangat rendah. Selain anak pasif dan tidak mau bertanya apabila menemui kesulitan belajar matematika. Oleh karena itu, Peneliti merasa bertanggung jawab terhadap kegagalan dalam pembelajaran. Adapun hasil pada pemberian preetest, dapat dilihat pada Tabel 1.

Tabel 1. Hasil pretest kelas VII-1 SMP Negeri 32

\begin{tabular}{|c|c|c|c|}
\hline Nilai & $\begin{array}{c}\text { Jumlah } \\
\text { Siswa }\end{array}$ & $\begin{array}{c}\text { Persentasi } \\
\text { \% }\end{array}$ & Ket \\
\hline$<80$ & 18 & $56,2 \%$ & KKM \\
& 18 & $43,8 \%$ & \\
\hline
\end{tabular}

Pada Tabel 1 dapat dilihat nilai siswa yang mencapai $K K M \geq 80$ sebesar 43,8\%. artinya Hasil belajar siswa ini masih tergolong rendah. Rendah hasil belajar tersebut dipengaruhi oleh beberapa faktor. Sutrisno (2016) menyatakan rendahnya hasil belajar dipengaruhi oleh tiga faktor yaitu metode, media dan motivasi belajar. Sutriningsih (Sutriningsih, 2017) menyatakan faktor yang mempengaruhi hasil belajar yaitu 1) keluarga, 2) lingkungan tempat tinggal, 3) kepribadian, dan 4) pembebanan. Selain itu, Ardila dan Hartanto (2017) menemukan bahwa penyebab rendahnya hasil belajar yaitu 1) kurangnya minat siswa terhadap pelajaran matematika, 2) kurangnya konsentrasi siswa selama proses pembelajaran, 3) rendahnya pemahaman konsep siswa, serta 4) kurangnya kedisiplinan siswa.

Berdasarkan hasil observasi, pada proses pembelajaran ditemukan fakta yaitu 1) banyak siswa yang mengobrol dengan teman sebangkunya, 2) banyak siswa yang merasa bosan di kelas, 3) kurang memperhatikan apa yang disampaikan guru, 4) jika diminta untuk bertanya hanya sedikit yang berani dan itu pun hanya pada siswa - siswa tertentu saja. 5) Siswa tidak langsung mengerjakan jika guru memberikan latihan atau Pekerjaan Rumah (PR) melainkan menunggu pekerjaan dari teman - temannya. Untuk mengatasi persoalan tersebut, yang lebih tepat diperbaiki 
adalah metode pembelajarannya. Selain itu, selama ini Guru telah berusahan meningkatkan hasil belajar siswa. Beberapa model pembelajaran telah diterapkan tetapi hasil yang diinginkan belum sesuai. Hal inilah yang melatar belakangi peneliti untuk meneliti aktivitas dan hasil belajar siswa melalui penerapan model pembelajaran yang tepat.

Beberapa penelitian menunjukkan bahwa metode pembelajaran yang dapat digunakan untuk meningkatkan hasil belajar siswa (Septiana, Sunardi, \& Oktavianingtyas, 2017; Subroto \& Slameto, 2015). Salah satu model pembelajaran yang cocok dan dirancang untuk membuat siswa aktif dan termotivasi yaitu Team Assisted Individualization (TAI) (Slavin, 1983). selain beberapa penelitian terkait TAI berhasil meningkatkan hasil belajar (Natalia \& Leonard, 2015; Pajriana \& Puji Lestari, 2015) , meningkatkan pemahaman konsep (Nadianti, Misdalina, \& Kesumawati, 2018; Putri, Musdi, \& Syafriandi, 2018) dan TAI meningkat kemampuan komunikasi matematis (Tinungki, 2015). Model pembelajaran ini adalah pembelajaran yang terdiri dari $4-5$ orang yang terbentuk dalam suatu kelompok, kelompok tersebut terdiri dari berbagai siswa yang memiliki kemampuan berfikir, suku, ras, jenis kelamin serta sosial ekonomi yang berbeda. Pada pembelajaran kelompok, siswa dituntut memiliki tanggung jawab untuk menyelesaikan permasalahan yang diberikan guru.

Berdasarkan identifikasi masalah yang telah diuraikan di atas, maka masalah yang dihadapi peneliti adalah sebagai berikut "Apakah dengan menggunakan model pembelajaran Kooperatif tipe TAI dapat meningkatkan aktivitas dan hasil belajar siswa kelas VII-1 SMP Negeri 32. Kecamatan sukajadi kota Pekanbaru Tahun 2018". Tujuannya yaitu 1) dapat meningkatkan Perhatian Siswa dalam mendengarkan Penjelasan Guru, 2) dapat meningkatkan kemampuan siswa mencatat materi yang disampaikan guru, 3) dapat meningkatkan keaktivan siswa dalam bertanya, dan 4) siswa dapat mengerjakan soal yang diberikan guru. Selain itu, penelitian ini diharapkan dapat berkontribusi dalam kajian teoritis dan bermafaat secara praktis meningkatkan hasil belajar siswa.

Artikel ini terdiri dari empat bagian. Pertama bagian latar belakang penelitian. kemudian, metode penelitian yang digunakan. Selanjutnya, bagian hasil penelitian dan artikel disimpulkan melalui bagian diskusi serta implikasi riset yang akan datang.

\section{METODE}

\section{Jenis Penelitian}

Penelitian ini merupakan Penelitian Tindakan Kelas (PTK). Penelitian ini dilaksanakan di SMP Negeri 32 Pekanbaru. Waktu penelitian dilaksanakan pada semester genap Tahun 2018. Waktu penelitian dilaksanakan dari tanggal 27 Februari sampai bulan 25 April 2018. Penelitian dilaksanakan dalam dua siklus penelitian masing masing siklus dilaksanakan dalam 3 kali pertemuan. Adapun urutan kegiatan penelitian adalah sebagai berikut :

Penelitian ini dilaksanakan dalam 2 siklus penelitian. Setiap siklus penelitian dilaksanakan dalam 3 kali pertemuan. Adapun kegiatan pembelajaran untuk setiap siklus penelitian dirancang sebagai berikut:

\section{Tahap perencanaan}

- Menyiapkan materi bahan ajar

- Menyiapkan pembentukan kelompok siswa beranggotakan 4 sampai 5 siswa dan memilih satu siswa sebagai ketua kelompok.

- Membuat Rencana Pelaksanaan Pembelajaran (RPP).

- Menetapkan dua guru sebagai observer

\section{Pelaksanaan Tindakan}

Tahapan ini merupakan tahapan penerapan dari kegiatan pembelajaran yang disusun dalam tahap perencanaan. 
- Guru menentukan suatu pokok bahasan yang akan disajikan kepada siswa, sebelum menyampaikan materi Guru menjelaskan kepada seluruh siswa tentang akan diterapkannya model pembelajaran kooperatif TAI dan pola kerja sama antar siswa dalam suatu kelompok.

- Guru menyiapkan materi bahan ajar yang harus dikerjakan secara berkelompok lalu guru memberiakn pre-tes kepada siswa untuk mengetahui sejauh mana pengetahuan siswa.

- Guru memberi materi baru secara singkat menjelang tugas kelompok

- Guru membentuk kelompok-kelompok kecil yang beranggotakan 4 sampai 5 siswa pada tiap kelompoknya. Kelompok dibuat heterogen tingkat kepandaianya dengan memperhatikan keharmonisan kerja kelompok dan memilih satu siswa sebagai ketua kelompok.

- Ketua kelompok melaporkan kepada guru tentang keberhasilan kelompoknya atau hambatan yang dialami anggota kelompoknya. Jika diperlukan guru memberikan bantuan secara Individu.

- Guru memberi tes kecil berdasarkan fakta yang diperoleh siswa serta Guru memberi materi kembali yaitu berupa latihan pendalaman secara klasikal yang menekankan strategi pemecahan masalah.

- Guru dapat memberikan tes formatif sesuai dengan tujuan pembelajaran yang ditentukan.

\section{Pengamatan}

Sesuai dengan indikator yang diharapkan tecapai, maka fokus pengamatannya sebagai berikut :

- Mengamati aktivitas siswa dalam belajar, yaitu diskusi dengan sesama anggota kelompok, keberanian siswa untuk mengemukakan pendapat dalam kelompok.

- Mengamati cara menerapkan model pembelajaran Kooperatif, agar diperoleh cara penerapan yang efektif.

- Observer mengamati guru dalam menerapkan model pembelajaran Kooperatif tipe Team Assisted Individual

\section{Refleksi}

- Mengevaluasi semua aktivitas pada siklus I yang sudah berjalan untuk memperbaiki pada siklus II.

- Refleksi dilakukan bersama obcerver.

\section{Jadwal Kegiatan Penelitian Tindakan Kelas}

Adapun jadwal pelaksanaan kegiatan siklus pertama dilaksanakan pada minggu ketiga dan keempat bulan Februari 2018, sedangkan siklus kedua dilaksanakan akhir Minggu pertama dan kedua bulan April 2018.

\section{Subjek Penelitian}

Subjek dalam penelitian ini adalah penggunaan model pembelajaran Kooperatif tipe TAI untuk meningkatkan prestasi belajar pelajaran matematika siswa Kelas VII-1 di SMP Negeri 32 Pekanbaru tahun 2018 dengan jumlah 36 siswa, yaitu laki-laki 16 anak dan perempuan 20 anak.

\section{Data Penelitian}

Adapun data penelitian diperoleh dari:

\section{Data Aktivitas belajar siswa}

Data aktivitas belajar siswa diperoleh dari hasil observasi guru terhadap proses belajar siswa yang meliputi: 1) Mendengarkan dan memperhatikan penjelasan guru, 2) Membuat catatan dari 
materi yang disampaikan oleh guru, 3) Aktif dalam bertanya, dan 4) Mengerjakan soal - soal yang telah diberikan oleh guru dalam mengikuti kegiatan proses belajar mengajar.

2. Data Hasil Belajar Kelompok

Data hasil belajar kelompok siswa diperoleh dari hasil observasi guru terhadap proses diskusi siswa yang meliputi: 1) Aktif bertanya dalam diskusi, 2) Aktif Mengemukakan pendapat dalam diskusi, 3) Menjawab pertanyaan kelompok lain, dan 4) Merangkum hasil diskusi dalam mengikuti kegiatan diskusi kelompok.

3. Data hasil Belajar Siswa

Data hasil belajar siswa diperoleh melalui tes setelah proses kegiatan belajar mengajar selesai maka dilaksanakan evaluasi melalui tes ulangan harian sehingga diperoleh data hasil belajar siswa.

Untuk mengumpulkan data, diperlukan suatu alat penelitian yang akurat, karena hasilnya sangat menentukan mutu penelitian. Teknik pengumpulan data yang digunakan dalam peneltitan ini adalah teknik tes dan non tes. Teknik tes digunakn untuk mengetahui data hasil belajar siswa, sedangkan teknik non tes dalam penelitian ini menggunakan lembar observasi yang digunakan untuk mengetahui aktifitas siswa dan diskusi kelompok dan kinerja guru

\section{Analisis Data Penelitian}

Analisis data. Analisis data dilakukan sejak awal pada setiap aspek penelitian. Begitu juga pada pencatatan lapangan dilakukan pada saat proses pembelajaran di kelas, peneliti langsung menganalisis segala yang dilihat dan teramati, baik mengenai situasi kelas serta hubungan antar siswa. Data yang diperoleh akan dianalisis dengan menggunakan analisis kualitatif dan analisis kuantitatif.

\section{Analisis Kualitatif}

Analisis ini digunakan untuk menganalisis hasil observasi digunakan untuk mengetahui aktivitas belajar siswa dalam interaksi pembelajaran, analisis aktivitas belajar siswa dan hasil kerja kelompok dengan model Kooperatif tipe Team Assisted Individual.

\section{Analisis kuantitatif}

Analisis ini digunakan untuk mendeskripsikan hasil belajar siswa dalam hubungannya dengan penguasaan materi yang diajarkan guru.

\section{HASIL}

Data pada penelitian ini terdiri dari data hasil observasi dan data hasil pelaksanaan pembelajaran yang diperoleh dari siklus I dan II. Pada saat pelaksanaan penelitian, peneliti dan observer bersama dalam melakukan kolaborasi penelitian ini. Berdasarkan hasil observasi, guru telah melakukan langka-langkah sesuain dengan model pembaelajaran TAI.

\section{Aktivitas Belajar Siswa}

Data hasil pengamatan selama siklus 1 sampai dengan siklus 2 dapat diperoleh rata-rata siswa yang aktif mengikuti kegiatan belajar mengajar.

Tabel 2. Rekapitulasi Data Aktivitas Siswa dalam Mengikuti Kegiatan Belajar dengan Menggunakan Model Kooperatife Tipe Team Assisted Individualization

\begin{tabular}{|c|l|c|c|c|c|c|c|}
\hline \multirow{2}{*}{ No } & Aktivitas Siswa & \multicolumn{3}{|c|}{ Siklus 1 } & \multicolumn{3}{c|}{ Siklus 2 } \\
\cline { 3 - 7 } & & Pert 1 & Pert 2 & Pert 3 & Pert 1 & Pert 2 & Pert 3 \\
\hline 1 & Prosentase siswa & $52,8 \%$ & $66,7 \%$ & $72,2 \%$ & $77,8 \%$ & $86,1 \%$ & $88,9 \%$ \\
\hline 2 & yang aktif & \multicolumn{3}{|c|}{$63,9 \%$} & & \multicolumn{3}{c|}{$84,3 \%$} \\
\hline
\end{tabular}


Berdasarkan Tabel 2 dapat dilihat siswa yang aktif mengikuti kegiatan belajar mengajar sebesar Pada siklus 1 sebesar 63,9\%, sedangkan pada siklus 2 meningkat menjadi sebesar 84,3\%. artinya terjadi peningkatan sebesar $20,4 \%$. Peningkatan aktivitas akan membawa dampak pada perubahan hasil belajar siswa.

\section{Hasil Belajar Kelompok Siswa}

Tabel 3. Rekapitulasi data hasil belajar kelompok siswa dalam mengikuti kegiatan belajar dengan menggunakan model Kooperatife tipe Team Assisted Individual.

\begin{tabular}{|c|c|c|c|c|c|c|c|}
\hline \multirow[t]{2}{*}{ No } & \multirow{2}{*}{$\begin{array}{l}\text { Aktivitas Siswa dalam diskusi } \\
\text { kelompok katagori baik }\end{array}$} & \multicolumn{3}{|c|}{ Siklus 1} & \multicolumn{3}{|c|}{ Siklus 2} \\
\hline & & Pert 1 & Pert 2 & Pert 3 & Pert 1 & Pert 2 & Pert 3 \\
\hline 1 & Aktif bertanya dalam diskusi & $27,8 \%$ & $36,1 \%$ & $44,4 \%$ & $50,0 \%$ & $58,3 \%$ & $66,7 \%$ \\
\hline 2 & $\begin{array}{l}\text { Aktif Mengemukakan pendapat } \\
\text { dalam diskusi }\end{array}$ & $33,3 \%$ & $41,7 \%$ & $50,0 \%$ & $55,6 \%$ & $61,1 \%$ & $69,4 \%$ \\
\hline 3 & $\begin{array}{l}\text { Menjawab pertanyaan } \\
\text { kelompok lain. }\end{array}$ & $38,9 \%$ & $47,2 \%$ & $52,8 \%$ & $61,1 \%$ & $66,7 \%$ & $72,2 \%$ \\
\hline 4 & Merangkum hasil diskusi & $55,6 \%$ & $61,1 \%$ & $66,7 \%$ & $72,2 \%$ & $75,0 \%$ & $77,8 \%$ \\
\hline & $\begin{array}{l}\text { Rata-rata Aktivitas Siswa dalam } \\
\text { diskusi kelompok katagori baik }\end{array}$ & \multicolumn{3}{|c|}{ Siklus 1} & \multicolumn{3}{|c|}{ Siklus 2} \\
\hline 1 & Aktif bertanya dalam diskusi & \multicolumn{3}{|c|}{$36.1 \%$} & \multicolumn{3}{|c|}{$58.3 \%$} \\
\hline 2 & $\begin{array}{l}\text { Aktif Mengemukakan pendapat } \\
\text { dalam diskusi }\end{array}$ & \multicolumn{3}{|c|}{$41.7 \%$} & \multicolumn{3}{|c|}{$62.0 \%$} \\
\hline 3 & $\begin{array}{l}\text { Menjawab pertanyaan } \\
\text { kelompok lain. }\end{array}$ & \multicolumn{3}{|c|}{$46.3 \%$} & \multicolumn{3}{|c|}{$66.7 \%$} \\
\hline 4 & Merangkum hasil diskusi & \multicolumn{3}{|c|}{$61.1 \%$} & \multicolumn{3}{|c|}{$75.0 \%$} \\
\hline
\end{tabular}

Data hasil pengamatan selama siklus 1 diperoleh rata-rata siswa Aktif bertanya dalam diskusi katagori baik sebesar 36,1\%, aktif mengemukakan pendapat dalam diskusi dalam katagori baik sebesar 41,7\%, menjawab pertanyaan kelompok lain katagori baik sebesar 46,3\%, merangkum hasil diskusi katagori baik sebesar 61,1\%.

Data hasil pengamatan selama siklus 2 diperoleh rata-rata siswa Aktif bertanya dalam diskusi katagori baik sebesar 58,3\%, aktif mengemukakan pendapat dalam diskusi dalam katagori baik sebesar 62,0\%, menjawab pertanyaan kelompok lain katagori baik sebesar 66,7\%, merangkum hasil diskusi katagori baik sebesar 75,0\%.

Terjadi peningkatan yang cukup dari siklus 1 ke siklus 2 yaitu diperoleh rata-rata siswa Aktif bertanya dalam diskusi katagori baik meningkat sebesar 22,2\%, aktif mengemukakan pendapat dalam diskusi dalam katagori baik meningkat sebesar 20,4\%, menjawab pertanyaan kelompok lain katagori baik meningkat sebesar 20,4\%, merangkum hasil diskusi katagori baik meningkat sebesar $13,9 \%$. Terjadinya peningkatan dalam kerja kelompok akan mendorong peningkatan hasil belajar siswa. 


\section{Hasil Belajar Siswa}

\section{Tabel 26. Rekapitulasi hasil belajar Siswa dengan menggunakan model Kooperatife tipe Team Assisted Individual}

\begin{tabular}{|c|l|l|l|l|l|c|c|}
\hline No & \multicolumn{1}{|c|}{$\begin{array}{c}\text { Hasil Belajar } \\
\text { siswa } \geq 80\end{array}$} & \multicolumn{3}{|c|}{ Siklus 1 } & \multicolumn{3}{c|}{ Siklus 2 } \\
\cline { 3 - 8 } & Pert 1 & Pert 2 & Pert 3 & Pert 1 & Pert 2 & Pert 3 \\
\hline 1 & $\begin{array}{l}\text { Prosentase siswa } \\
\text { yang tuntas } \\
\text { belajar }\end{array}$ & $55,6 \%$ & $66,7 \%$ & $77,8 \%$ & $83,3 \%$ & $86,1 \%$ & $91,7 \%$ \\
\hline 2 & Rata-rata & \multicolumn{3}{|c|}{$66,7 \%$} & & \multicolumn{3}{c|}{$87,1 \%$} \\
\hline
\end{tabular}

Dari hasil belajar pada siklus I siswa yang tuntas belajar dari pertemuan 1, 2 dan 3 rata-rata adalah 66,7\% pada siklus ke 2 meningkat menjadi 87,1\% naik sebesar 20,4\% Ketidak tuntasan belajar siswa disebabkan kemampuan kongkrit mereka yang kurang, oleh karena itu perlu bimbingan dan perhatian dari guru, dari hasil tersebut menunjukkan bahwa indikator hasil belajar 91,6\% siswa yang memperoleh nilai 80 sudah tercapai pada siklus 2 .

\section{PEMBAHASAN}

Penelitian Tindakan Kelas ini dilaksanakan dalam dua siklus. Setiap siklusnya terdiri dari perencanaan, pelaksanaan, observasi dan refleksi. Pada pertemuan pertama siklus I, aktifitas dan hasil belajar siswa belum memenuhi kriteria ketuntasan yang telah ditetapkan. Hal ini disebabkan karena guru sudah berusaha namun belum optimal dalam proses pembelajaran. Adapun kelemahan pada pertemuan pertama antara lain: 1) Keaktifan bertanya siswa rendah, 2) Keaktifan siswa mengemukakan pendapat rendah, 3) Keaktifan menjawab pertanyaan kelompok lain rendah. 4) Mendengarkan dan memperhatikan penjelasan guru masih kurang, dan 5) Membuat catatan dari materi yang disampaikan oleh guru masih kurang.

Sedangkan pada akhir siklus I, aktifitas dan hasil belajar siswa sudah memenuhi kriteria ketuntasan yang telah ditetapkan. Tetapi masih terdapat kelemahan yang perlu diperbaiki, yaitu: 1) Keaktifan bertanya siswa masih kurang, 2) Keaktifan siswa mengemukakan pendapat sudah dapat ditingkatkan tapi belum maksimal, 3) Membuat catatan dari materi yang disampaikan guru perlu ditingkatkan, dan 4) Keaktifan bertanya masih perlu ditingkatkan.

Pada akhir siklus II, aktifitas dan hasil belajar siswa sudah memenuhi kriteria ketuntasan yang telah ditetapkan. Hal ini disebabkan karena guru sudah berusaha optimal dalam memperbaiki pengolahan pembelajaran, hanya tinggal 3 siswa yang tidak tuntas, disebabkan oleh kemampuan penalaran siswa yang kurang.

Dari hasil perbaikan pembelajaran yang telah peneliti lakukan dengan menggunakan model Kooperatife tipe TAI maka dapat diketahui bahwa melalui model kooperatif tipe TAI dapat meningkatkan aktivitas belajar siswa kelas VII-1 SMP Negeri 32 Pekanbaru Tahun 2018. Hal ini dapat dilihat pada siklus 1 sampai dengan siklus 2 yaitu diperoleh rata-rata siswa yang aktif mengikuti kegiatan belajar mengajar, pada siklus 1 siswa yang aktif mengikuti kegiatan belajar mengajar sebesar $63,9 \%$, sedangkan pada siklus 2 meningkat menjadi $84,3 \%$, terjadi peningkatan sebesar 20,4\%. Peningkatan aktivitas akan membawa dampak pada perubahan hasil belajar siswa. Dengan model Kooperatife tipe TAI dapat meningkatkan hasil belajar siswa kelas VII-1 SMP Negeri 32 Pekanbaru Tahun 2018 Hal ini dapat dilihat pada siklus 1 sampai dengan siklus 2 yaitu dari hasil belajar pada siklus I siswa yang tuntas belajar dari pertemuan 1, 2 dan 3 rata-rata adalah 66,7\% pada siklus ke 2 meningkat menjadi 87,1\% naik sebesar 20,4\%. Adapun saran bagi para praktisi atau guru yaitu: agar pembelajaran lebih menarik dan mudah dipahami siswa, hendaknya menggunakan model Kooperatife tipe TAI.. 


\section{PENGHARGAAN}

Terima kasih peneliti ucapkan untuk Muhammad Salim, S.Pd. Selaku kepala sekolah SMP Negeri 32 Pekanbaru karena telah memberi kesempatan untuk melaksanakan penelitian ini. Terima kasih juga peneliti sampaikan kepada guru-guru yang telah memberikan kritik dan saran pada kegiatan seminar penelitian ini.

\section{REFERENSI}

Aminah, H. S. (2017). Meningkatkan Hasil Belajar IPA melalui Model Kooperatif Tipe Jigsaw Berbantu Media Gambar Kelas IV SD. Jurnal Pendidikan Progressif, 7(2), 93-100.

Ardilla, A., \& Hartanto, S. (2017). Faktor yang mempengaruhi Rendahnya Hasil Belajar Matematika Siswa MTs Iskandar Muda Batam. Phytagoras, 6(2), 175-186.

Bernas.id. (2017). Peringkat Berapakah Indonesia di TIMSS? Retrieved from https://www.bernas.id/50899-peringkat-berapakah-indonesia-di-timss.html

Gagne, R. M. (1983). Learning Outcomes and Their Effects (Useful Categories of Human Performance). American Psychologist, 39(4), 377-385.

Kurniawan, B., Wiharna, O., \& Permana, T. (2017). Studi Analisis Faktor-Faktor yang Mempengaruhi Hasil Belajar pada Mata Pelajaran Teknik Listrik Dasar Otomotif. Journal of Mechanical Engineering Education, 4(2), 156-162.

Maysarah, S. (2018). Peningkatan Hasil Belajar MAtematika Siswa Melalui Strategi PAKEM di KElas VIII MTs Nurul Amaliyah Tanjung Morawa. Jurnal Tarbiyah, 25(1), 125-144.

Nadianti, R., Misdalina, \& Kesumawati, N. (2018). Perbandingan Model Pembelajaran Kooperatif Tipe TAI dengan NHT dalam Kemampuan Pemahaman Konsep Matematis ditinjau dari Kemampuan Awal Siswa SMP Negeri 4 Prabumulih. Jurnal Kajian Pembelajaran Matematika, 2(April), 19-25.

Natalia, \& Leonard. (2015). Pengaruh Metode Pembelajaran Team Assisted Individualization Terhadap Hasil Belajar Matematika pada Sekolah Menengah Kejuruan Darul Ma'arif Jakarta. In Seminar Nasional Pendidikan Matematika Universitas Indraprasta PGRI. Jakarta: Universitas Indraprasta PGRI.

Nuraheni, E. (2016). Indonesia's PISA results show need to use education resources more efficiently. Retrieved from http://theconversation.com/indonesias-pisa-results-show-needto-use-education-resources-more-efficiently-68176

Pajriana, I., \& Puji Lestari. (2015). Pengaruh Metode Pembelajaran Team Assisted Individualization (TAI) terhadap Hasil belajar Matematika Siswa. Jumal Media Pendidikan Matematika "I-MPM," 4(2), 64-69.

Putri, M. D., Musdi, E., \& Syafriandi. (2018). Pengaruh Model Pembelajarab Kooperatif Tipe Team Assisted Individualization terhadap Kemampuan Pemahaman Konsep Matematika Peserta Didik. Jurnal Pendidikan Matematika, 7(1), 24-29. 
Septiana, S. W., Sunardi, \& Oktavianingtyas, E. (2017). Pengaruh Hasil Belajar Matematika Terhadap Kecerdasan Emosional Siswa Kelas IX SMP Negeri 13 Jember. Kadikma, 8(1), 105-111.

Slavin, R. E. (1983). Team-Assisted Individualization: A Cooperative Learning Solution for Adaptive Instruction in Mathematics. Baltimore.

Subroto, D., \& Slameto. (2015). Peningkatan Hasil Belajar Matematika Menggunakan Metode Pembelajaran Problem Solving pada Siswa Sekolah Dasar. Jurnal Pendidikan Dasar, 4(2), 79 86.

Sutriningsih, N. (2017). Penyebab Siswa Underachiever dalam Pembelajaran Matematika. Jurnal Edumath, 3(2), 148-154.

Sutrisno, V. L. P. (2016). Faktor-Faktor yang Memepengaruhi Hasil Belajar Siswa pada Pembelajaran Praktik Kelistrikan Otomotif SMK di Kota Jogjakarta. Jurnal Pendidikan Vokasi, 6(1).

Syafwan. (2013). Meningkatkan Hasil Belajar Matematika Siswa Melalui Strategi Pembelajaran Kooperatif Tipe Tutor Sebaya Untuk Siswa Kelas VII-A SMP Negeri 2 Poso Pesisir. Jurnal Kreatif Tadulako Online, 4(4), 227-238.

Tinungki, G. M. (2015). The Role of Cooperative Learning Type Team Assisted Individualization to Improve the Students ' Mathematics Communication Ability in the Subject of Probability Theory. Journal of Education and Practice, 6(32), 27-31.

Yusuf, M. (2010). Peningkatan Hasil Belajar Matematika Siswa Melalui Lembar Kerja Siswa (LKS) Interaktif Berbasis Komputer di SMA Muhammadiyah 1 Palembang. Jurnal Pendidikan Matematika, 4(2), 34-44. 